\title{
The Medici Archives
}

R ARELY, if ever, can documents concerning a single family $\mathbf{Q}$ have come into the market which have such a range as A. D. 1084 to 1771 and are of such importance as the Medici archives which are to meet their fate at Christie's on 4 February and the three following days. ${ }^{1}$ They form, needless to say, a collection of consummate interest for all students of Italian history. The name Medici first appears in the second document, dated 5 December 1240, which relates to the bankruptcy of Guido Guerra, whom Dante has immortalized in canto svi of the Inferno. In this Ugo and Galgano de' Medici appear among the creditors. The earliest Medici mentioned in the catalogue as holding public office is Bonino, who as Gonfalonier of Justice grants a pardon, which is signed by Salvi Medici, notary public. The Medici, however, had been before this a powerful and troublesome family throughout the stormy times which preceded and followed Dante's exile.

The first section of the documents is mainly concerned with deeds of gift and sale, marriage contracts, wills, receipts, powers of attorney, legal opinions, presentations to benefices, papal briefs, patents of naturalization and nobility. An illustration is given of one of two briefs by Leo $X$, written and signed in the beautiful handwriting of Bembo.

From an historical and biographical point of view the chief value of the collection consists in Lorenzo's letters, of which 166 are holograph, and which, together with other political documents, form the second and third sections of the catalogue. Most of the letters were written to Pietro Alamanni, Florentine ambassador first at Milan and then at Rome, beginning with 11 .May 1489 and ending with 20 March 1492, very shortly before Lorenzo's death. With these are many dispatches from the Otto di Pratica, a committe for affairs of state, and some from the official government, the Signoria. There is, however, a gap from October 1489, the close of Alamanni's embassy to Milan, until his arrival at Rome early in 1491. This correspondence was, as was cus-

1 Catalogme of the Hedici Anchives, the property of the Marquis Casima de' Medici and the Harquis Averardo de' Hedici (1917). 
tomary until long afterwards, the property of the ambassador. The present owners are the descendants of Giovenco, second son of Averardo, who died in 1314, from whom Cosimo and his brother Lorenzo, ancestor of the grand-ducal line, were derived in the fourth degree of the elder line. Raffaello de' Medici (1543-1628) married Costanza Alamanni, who in all probability brought these documents to the junior branch of Medici. A few other letters of interest are also comprised in the second section, notably one from the good-nstured Leonello d'Este to Lorenzo's grandfather Cosimo, begging him to have no reserve, but to 'open his bag' as he would to a son, and several from Ludovico il Moro. Mlustrations of the caligraphy of these notabilities are printed, as is one of a letter from Caterina Sforza. Charles VIII of France also figures among Lorenzo's correspondents.

Pietro Alamanni was Lorenzo's intimate friend. He was knighted by Ludovico il Moro before leaving his post at Milan, and was intended to act as ambassador at Naples. On reaching Rome, however, he was detained by Lorenzo's orders, and was here 'coached' by Pier Filippo Pandolfini, who had represented Florence at the Vatican since Lanfredini's death. Alamanni was apparently modest as to his ability to cope with a group of clever and experienced cardinals belonging to different political factions. He wrote, however, that he had visited most of them with Pandolfini, and found them much like ordinary men : when young he had to please several ladies at the same time, and often with success, but Lorenzo knew that he had failed one St. Lucy's eve, and, with all his goodwill, this might happen with one of the cardinals. Lorenzo replied on 15 January 1491 that he knew that as a young man Alamanni had to keep two or three ladies amused together, and that the cardinals would give him no greater trouble: all that was needful was to be discreet, to say nothing that could displease any one who confided in him, to try and gain with everybody, and lose with no one. This was the ideal of diplomacy which Lorenzo impressed upon his envoys. These letters of Lorenzo have never apparently been utilized. Fabronius has printed several addressed to Alamanni's predecessor at Rome, Lanfredini, and B. Buser in Lorenzo als Staatsmann gives one addressed to Alamanni on 17 May 1491, but this does not exactly correspond with any analysed in the catalogue. As is often the case, the reader is tantalized by only getting one side of the correspondence, but, if Alamanni's books of minutes for his letters should fall to the same purchaser, they would to some extent fill the gap.

Lorenzo's chief task was to prevent a renewal of the recent war between Innocent VIII and Ferrante of Naples. The king still held captive some of his barons, whom Innocent thought 
secured by the treaty of peace, and whose release he, as suzerain of Naples, peremptorily ordered. Ferrante also refused to pay the customary tribute, which had indeed been waived by Sirtus IV. The quarrel was accentuated by the revolt of Ascoli, the picturesque city on the Tronto, often a bone of contention between the papacy and Naples; the citizens had added to this iniquity by raiding the little papal town of Offida. Ferrante marched troops up to his frontier under Virginio Orsini, a near relation of Lorenzo's wife, who had left Florentine service for the purpose. Thus was trailed a coat on which the passionate pope was only too much inclined to tread. Lorenzo's plan was that the two neutral members of the long triple alliance between Milan, Florence, and Naples should combine in effecting a reconciliation. He was sincerely antrious to protect the pope, whose son Franceschetto Cibò had married his daughter. Innocent was not a comfortable client for a would-be mediator. Lanfredinihad described him on 21 October 1489 as a perfect simpleton, whose passion was such that if Lorenzo alone gave him any encouragement, he would do violence to his own instincts, both in the matter of spending money, and in seeking adherents outside Italy. ${ }^{3}$ Innocent threatened Ferrante with deprivation and interdict, and Virginio Orsini with excommunication, an operazione diabolica, as Lorenzo called it. He had thoughts of retiring to Avignon, which his mentor told him would do no good at all. On the other hand, Lorenzo's professed partner in the mediation was a most untrustworthy ally. Ludovico il Moro mistook complexity for cleverness : he was never content with one combination at a time. Lorenzo believed that he did not himself know what he wanted, that he would finally act as his mood dictated, and end of his own accord by giving himself away . cheap. This is precisely what was to happen in later years. Ludovico's natural inclination would have been towards Ferrante, who had helped him to the government of Milan, and whose grand-daughter had married the young duke, Ludovico's nephew and ward. The marriage, however, was not a success; several of Lorenzo's letters relate to a project of Ludovico for engineering a divorce between the young couple and marrying the wife himself. This, thought Lorenzo, might satisfy Ferrainte; but the scheme came to nothing, and Ludovica married Beatrice d'Este, the prime cause of the rupture with Naples and of the troubles of Italy throughont coming centuries. Between the pope's ill humour towards himself and Ludovico's bad manners towards the pope, Lorenzo confessed that he did not know where he stood.

Alamanno was, after all, right in his original nervousness as

- Buser, Dic Beziehwngen der Mediceer zu Frankreich, 14\$4-Q4, P. 522. 
to dealing with cardinals. Never had faction run so high in the college as among the wealthy, high-born cardinals whom the old pope, at once weak, obstinate, and passionate, was quite unable to control. Lorenzo's letters constantly refer to il Maleacense as being the evil genius at Rome. This worthy is not identified in the catalogue; he was Federigo da San Severino, son of Innocent's late captain-general, Roberto, count of Caiazzo, who, when bishop-elect of Maillezaix (a suffragan see of Bordeaux), had been nominated cardinal with Giovanni de' Medici. Lorenzo was anxious to keep his son from contact with him, and it may be noted that long after his death the Cardinal Medici and the Cardinal San Severino respectively represented Pope Julius II and the schismatic council of Pisa in the battle of Ravenna. This pope, as Cardinal Givliano della Rovere, was also suspected by Lorenzo, but, as he was a rival of il Maleacense, Alamanni was instructed to be civil to him. Lorenzo's chief reliance was on the Genoese cardinal of Santa Anastasia, whose favour he thought cheaply bought by the reversion of a Florentine benefice of 200 ducats, the occupant of which, his own natural brother, was in excellent health at the time of writing.

It was clear that a conflict between Rome and Naples could not be localized; it could not even be confined to Italy. The northern, western, and eastern powers were all on the look out. The pope was alarmed at the news that Matthias Corvinus had occupied Ancons and was intriguing with the lords of Camerino and Pesaro. As the king's second wife was the daughter of Ferrante it looked as if there were a combination between Hungary, Naples, and the papal feudatories of Romagna and the March. Ludovico's action was also even peculiarly ambiguous. MIatthias, however, convinced Innocent that his getion was directed against Venice, who had robbed the Hungarian crown of the Dalmatian çosst. Matthias had an interest in cajoling Innocent with a view to the transfer to himself of Prince Djem, whom he wished to utilize in his intended campaign against Bajazet. Lorenzo had hinted at an alliance between Florence, Venice, and the pope, if pressure upon the last became serious. He dissuaded Innocent from surrendering the custody of Djem, who had been entrusted to his care under special conditions by. the king of France, the breach of which might cause grave offence.

The death of Matthias removed one danger to promote another. It is interesting to find that from this time Maximilian was feared in Italy. On 27 January 1492 Lorenzo advised Innucent to keep on good terms with him as he would probably be emperor'It seems to me that he may serve the pope as a stick for all the dogs, for every man in Italy is afraid of him.' On 6 February he adds that Venice in fear of Maximilian wants a general Italian 
league : the pope should decline, for Maximilian thinks that Italy is hostile, and if the pope joined the league he might be thought to share those feelings; there was time enough to join the league when Maximilian threatened Italy. On the other hand, Innocent was warned not to alienate Maximilian's enemies. Thus, when the news arrived of Charles VIII's intended marriage with Anne of Brittany, already married by proxy to Maximilian, the pope was in a quandary. Lorenzo could only advise that, on Charles's request for a dispensation, Innocent should procrastinate by the usual resource of a committee. His penultimate letter before his desth recommends the dispensation, mainly it would appear to stop some scandal about himself. The diplomatist who is often mentioned as well fitted to negotiate between Maximilian and Charles VIII is Raymond Perault, archdeacon of Aulnis in Saintonge, and afterwards one of Marimilian's chief counsellors. He is represented as being a good man and popular both in France and Germany. Yet another danger to Italy, as Lorenzo thought, was threatened by the intervention of Ferdinand and Isabella in the dispute between the pope and Naples. Their purpose was ambiguous : either they might be backing their relation in more drastic action against the pope, or, yet more perilous, they might be currying favour with the latter with a view to the replacement of the illegitimate line at Naples by the legitimate branch of Aragon. Lorenzo could never rest until their envoys had left Rome; Granada from henceforth occupied all their energies.

Rome and Naples finally made peace behind Lorenzo's back. He professed to be greatly pleased, but his letters prove that the neglect had nettled him. He advised Alamanni to keep clear of the negotiations for fear of alienating Charles VIII, who would not like them; he stated that the peace was unpopular throughout Italy, and expressed a somewhat scornful opinion on the likelibood of its permanence. In the later stage of negotiations Ludovico il Moro had almost dropped out of the picture. His marriage with Bestrice d'Este and the rivalry between her and her cousin the duchess had made him unacceptable to Ferrante as a mediator. Lorenzo, too, had a poor opinion of his diplomatic ability; Ludovico was, indeed, too subtle to be sound.

It may be confessed that these papers relate to the least eventful period of Lorenzo's career, because his fortunes and those of Florence were not directly involved in the dispute between the pope and Naples, though, of course, in the delicate balance of power, and under the covetous eyes of three grest ultramontane or altramarine states, the slightest shock might bring ruin upon all Italy. The value of the letters consists mainly in their admirable illustration of Lorenzo's diplomatic methods, and even of his character, now that years and ill health had tempered the more adven- 
turous impulses of his youth. At this crisis he was all against adventure; his aim was compromise which should leave neither pope nor king the stronger. Yet compromise must not be too rapid, or he would lose the strong position which his mediation gave. There was probably, too, a very human element of jealousy; he must be the universal homme nécessaire, must know everything, influence everybody, and decide everything. As he was not technically ruler of the state he frequently acted through independent agencies. Sometimes he employed a private envoy side by side with the official embassy, or the agents of the Medici bank, for instance the Sassetti and Spinelli of Lyons, to whom there are several references in these letters. In this case, however, he is acting through the regular ambassador. Yet the reader will see at once that Alamanni's correspondence with Lorenzo was far more intimate and important than was that with the Eight and the Signoria by whom he was formally accredited. The practical authority of the Signoria had for generations been shadowy, but the Eight were the committee for state affairs, which had formed an essential part of Lorenzo's constitutional experiments of 1480 ; they were selected for their experience, and not by the haphazard method which determined the personnel of the more dignified Signoria. Nevertheless, the Eight were left very much out in the cold, so much so that Lorenzo's secretary, Bibbiena, thought it prudent to warn Alamanni to write more often and more fully to the Eight, who had been heard to complain of the dryness of his dispatches; of course he need not let them into affairs which should remain secret between him and Lorenzo, but verbum sap. Not even much secretarial confidence is to be traced in Lorenzo's correspondence. All important letters are written in his own clear and careful hand, whether in cipher or not; he even copies himself the documents which he encloses, adding in one an imitation of Ferrante's efderly but florid autograph. His industry must have been portentous; in one letter he complains that he had been writing all day and was tired.

After full allowance for an element of vanity or self-interest the letters prove that Lorenzo had a genuine love for the peace of Italy and a horror of foreign intervention. Not only does he strive for peace between Rome and Naples, and the avoidance of all offence to Charles VIII and Maximilian, but he does his atmost to quench every spark which issues from the inflammable and explosive material in the little states which lie to east and south of Florence. Romagna had recently been disturbed by the murder of Girolamo Riario at Forli and that of Astorre Manfredi at Frenza. It was Lorenzo's task to support Riario's widow, Caterina Sforza, against the assassins; and to consolidate the government of Manfredi's heir. In several letters he urges 
the pope to be on more friendly terms with Caterina, if only for the sake of papal security. He persuades Innocent to recognize the prevailing families of Baglioni and Vitelli in Perugia and Citta di Castello, and so put an end to generations of faction. The exiles of one small state could always take refuge in another, and make it the basis of attack on the victorious government. Again and again Innocent is implored to encourage an alliance between Siena and Perugia and Urbino, and so put an end to the chronic restlessness. Through Lorenzo's agency much was really effected. If he finslly had no part in the actual terms arranged between Innocent and Ferrante, it is certain that but for him pope and king would long ago have been at war. It is the highest testimony to his pacific influence that the terrible Italian tragedy that was to follow was attributed to his untimely death.

The letters of Lorenzo, the Elight, and the Signoria contain many references to Florentine affairs unconnected with foreign politics. Alamanni was instructed to obtain the pope's permission for the settlement of Jews at Florence. The agreement with the moneylenders was renewed from time to time. On each renewal, urged the Eight, the city suffered, but a great city must have Jews: if usury were wrong, the Jews were the sinners, and the church had no concern with their souls, while the Christian borrowers were punished by having to pay an exorbitant rate of interest; if men had no Jews from whom to borrow money, they were driven to cheat and steal in order to get it. It may be mentioned that three years before this petition Fra Bernardino of Feltre was expelled from Florence after preaching in favour of a state pawnbroking institution. Such sermons frequently led to attacks upon resident Jewr. Alamanni also had to beg the pope to allow the assessors of taxes to examine the real ownership of property purporting to belong to persons in holy orders. Families were in the habit of fraudulently transferring all their property to one clerical member in order to escape taxation, although the other members actually remained in possession. This caused a grievous loss to the revenue, especially at a time when men seemed less willing to make any sacrifice for the state than they ever were before. It appears also that young Florentines of position were disinclined to sacrifice their celibate freedom. Lorenzo and his secretary Piero da Bibbiena had done their best to persuade Alfonso Strozti to marry Alamanni's daughter, but he had been evasive, though protesting that he would not marry against Lorenzo's orders. Many other Florentine gentlemen were also vainly tyying to marry off their daughters, if that were any consolation to Alamanni. It is notorious that Lorenzo laid great stress on his 
command of the matrimonial market; it was his resource against dangerous family cliques.

Church scandals form the subject of a good many letters. The Eight kept protesting against the interdict laid on three Florentine churches at the instance of Arnolfo de' Bardi on account of certain payments due to him. The priors of Assisi beg Lorenzo to implore the pope no longer to neglect the disorderly life of the nuns of Sante Chiara, which dishonoured the house where the saint's body was preserved. The men of Pieve San Stefano complained that they had built a convent for the Franciscan friars, who were now living in a disorderly manner. The Florentine Signoria pressed the pope to abolish the reservation of Florentine benefices for cardinals' nominees, and to keep them for Florentine clergy; the nominees were in many cases men of a vile and nnworthy description, and God's service was gravely prejudiced. The general of the Camaldunenses petitioned the cardinal of Siena for leave to reform the convent of San Benedetto, which badly needed it. Lorenzo writes that there was an outcry in Florence against an attempt of the Strozzi to eject the incumbent of Pieve di Ripoli, a very old man and yet more poor than old; Lorenzo had been moved by the old man's tears, and, though the whole Strozzi family would be at him, begged the pope to let him stay. The hunt for benefices was of course fast and furious throughout the church, and Lorenzo certainly led the pack. It would be tedious to enumerate the endowments for his son Giovanni which he begged of the pope through the agency of Alamanni. He would rather have ten benefices in Tuscany than thirty abroad, but the boy, not yet proclaimed cardinal, possessed thiem in the Milanese and the kingdom of Naples. Hints were made for the great abbey of Farfa, if the Orsini abbot were to die, and his family should quarrel over the succession. Alamanni was to watch for any benefice that fell vacant, for those in the Papal States were bestowed by the pope before the news reached Florence, and so too the French ones by the king in France. Charles VII himself made Lorenzo his broker, begging him to obtain a cardinalate for Pierre de Laval, archbishop of Rheims, protesting against the bestowal of Tournai on the cardinal of Santa Anastasia instead of on his faithful councillor, Louis Pot, and threatening, if the pope did not treat him fairly, to have recourse to means which he would be sorry to use. Alamanni was empowered to offer the notorious Cardinal Balue a tip (beveraggio) if he would facilitate negotiations. Balue's death offered a splendid opportunity, for it was said that his benefices were to bo divided at once ; Lorenzo was, indeed, touting for the bishopric of Angers for Giovanni while the cardinal was on his sick bed. 
Innocent's very catholic taste for wine was a valuable asset for Lorenzo. No reasonable man would regard a present of a few dozens as a tip or bribe. Lorenzo wished to wheedle benefices, to shorten the three years during which Giovanni's cardinalate was not to be published, and to soften the pope's heart towards Ascoli or the king of Naples. Couriers were consequently laden with all the bottles which they could carry of Vernaccia, which went as well with the ortolans which Innocent loved as with the eels so dear to Martin IV, or else with Casentino vermiglio or brusco, with the still excellent Montepulciano, or the vino greco which was sometimes hard to find in Florence or S. Gimignano. Alamanni in a letter of 19 April 1491 (not here printed) wrote that the pope asked for several bottles by letter post of wine that should be full flavoured, and not sweet but strong. Wine was supplemented by breadths of cloth, white, black, or pink, and the choicest damask. The donor's greatest wish, he wrote, was to keep him merry and cheerful. Lorenzo was indeed the most obliging of men; at the request of the Venetian ambassador at Rome he makes and forwards a collection of the songs both sweet and serious of the Bohemian composer, Heinrich Isask; at another time he gives much thought to a tomb for the great Francesco Sforza, but cannot think of a sufficiently worthy artist. In these years his health was failing fast. He had an idea in October 1491 of a visit to Rome to exercise his personal influence on the pope, as formerly, at the great crisis of his bife, on Ferrante of Naples. But his journeys now were from one sanstorium to another. In February 1492 his son Piero wrote to Alamanni that the gouty humours were spreading from the feet and hands all over his body, under the skin and in the joints and muscles; there was little fever, and Pier Leoni said there was no danger; he was strong and robust but very restless, and could not attend to any sort of business. Pier Leoni's diagnosis of the malady and analysis of the qualities of the several medicinal waters may still be read with interest by those of gouty temperament in Fabroni's Vita Laurentii Medicis Magnifici, ii. 391. The doctor, by the way, had, the patient tells Alamanni, given him a fright, because it was rumoured that he had fled from Padua owing to threatened persecution for practising the black arts. In March Lorenzo was unsble to talk over Milanese affairs with his close friend, Pier Filippo Pandolfini, who was on his way from Milan to Rome. A week later, on $10 \mathrm{March}$, Giovanni made his formal entrance into Florence as cardinal, and thus the great wish of his father's later years was gratified. His last letter is dated $20 \mathrm{March}$; on the night of 8 April he died.

The earlier part of the fourth section of the catalogue has 
not the same importance or continuous interest as those which precede it. The letters comprised in it are of a somewhat miscellaneous character, and their main value often consists in the autograph. But Francesco di Giuliano de' Medici held important offices in the state, and wes in constant touch with his cousins of the elder line and their intimate associates. Thus we find a letter from Giovanni, afterwards Leo $X$, written when a boy of nine, and, as the illustration proves, far better than those of most modern boys of three times his age. There are many from his good-natured brother Giuliano, and one from his sister Lucrezia Salviati. Others are from the hand of Poliziano, Pietro Ardinghelli, Federigo and Filippo Strozzi, and the latter's wife, danghter of the luckless Piero de' Medici. Among the most interesting documents is an apologis written to Francesco di Givliano's son Francesco by Lorenzino, the assassin of Duke Alessandro; of this a full copy is given. Francesco's son and great-grandson, both named Raffaello, were constantly in high employment under the ducal and grand-ducal lines. Thus all members of this second house of Medici are well represented from 1541 to 1601 . There are many letters of Cosimo I, one of his wife Fleanor of Toledo, many from the notorious Bianca Cappello and her husband Francesco I, and so forth down to Fernando I and his wife Christine of Lorraine. In Fernando's correspondence there are frequent allusions to the rebellion of the andacious Alfonso Piccolomini, which might have proved serious owing to the connexion of his family with Siena, which had none too willingly accepted the personal rule of the Florentine despots. Raffaello's manuscript book with cipher key containing copies of his dispatiches during his embassy at Ferrars in 1589 and 1590 must be a valuable sonrce for the politics of a critical time. Another document contains the instructions given to him by Christine of Lorraine on his mission to the court of Nancy. Raffaello was to suggest to her father, Charles II of Lorraine, that her husband should effect a reconciliation between him and Henry IV : good catholics, indeed, ought to have no dealings with Henry, but the catholic league had done nothing for the duke, and the war was only causing grievous suffering to Lorraine. In later pages are notes on letters from Cosimo II, Fernando II, Tilly, Richelieu, Louis XIII, and Louis XIV, followed by a list of grand-ducal proclamations and of ordinances on trades and professions.

The catalogue concludes with documents which are necessarily briefly mentioned, but which will certainly prove to be of the highest value for economic history. They consist of ledgers, account-books, and letter-books, mainly of the fifteenth and sirteenth centuries, and cover the whole ground of agricultural, 
manufacturing, and commercial life. On one document is a precious note in the handwriting of Cosimo, pater patriae. Many give prices of wine, agricultural produce, and stock down or up to donkeys. There are payments of tares, purchases and sales of government stock, termed Monte Comune, sales and leases of houses and shops in Florence. The Art of Wool occupies the longest place; here we have the prices of cloth and rate of wages throughout long years, the imports of raw wool from Spain. the export of cloths to Adrianople to be finished, the costs of transit from Florence to Ancona and thence to the Levant, or from Florence to Leghorn and forward to Lyons. Dealers and agents are found among Turks and Jews at Constantinople, Adrianople, Pera, Brusa, and Gallipoli, which seems to have been a centre for Syrian and Levantine trade. Other consignments pass to Ravenna, Ragusa, Rome, Messina, and Palermo. Closely connected with the woollen trade is the Art of Dyeing, and for that especially important is the supply of alum. In an earlier section Lorenzo solicits briefs from the pope to facilitate the recovery of alum purchased by Henry VII. Alum leads us to soap, and soap is a usual companion to spices and sugar. The Art of Silk and that of the Jewellers find ample illustration; the lururies extend to velvets, belts, purses, knives and forks of silver and gold, and all kinds of personal ornaments. Those who have ultimately to explore this mine of economic information are greatly to be envied.

The catalogue itself with its excellent introduction by $\mathrm{Mr}$. Royall Tyler, its full genealogies and beautiful reproductions of documents, is a book of high permanent value. ${ }^{3}$ It is impossible not to feel deep regret at the prospect of the breaking-up of this unique collection, even though portions of it may be made more a vailable for students of history than in the past. It is sincerely to be hoped that at least the correspondence of the years 1489 to 1492 may escape disruption, and in like manner the collection of economic documents. The ideal would be the restoration of the whole to Florence, and a permanent home in the Laurentian Library in preference to the somewhat dingy Archivio, to which scientifically they would belong.

E. ARarstrong.

- A fow misprintes mag be noticed: Vienns for Vience, p. 62; Aulwis for Aulnil, and Anflitis tor Anfidie (Offids), pp. 98,99. On p. 112, lot 429, which is a letter of Lorenzo to Alemanni when ambaciedor to Mfilen, dated 19 October 1489, in misplaced smons the documents of October 1491. 